\title{
Душевные недуги в традиционной культуре тюрко-монгольских народов Внутренней Азии: восприятие, причины, исцеление
}

\author{
Марина М. Содномпилова
}

Калмыцкий научный центр Российской академии наук, Российская Федерация

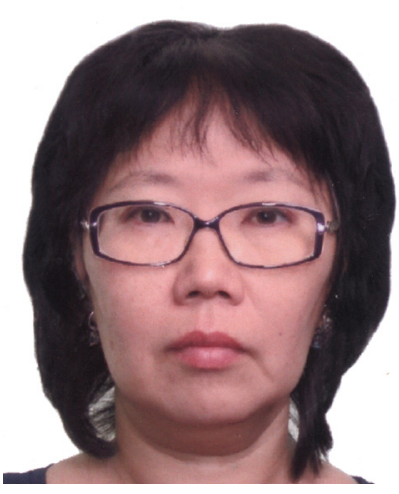

В число распространенных заболеваний, описываемых у народов Сибири (якутов, тувинцев, хакасов, бурят), входят различные виды душевных недугов, которые с ХІХ в. называли «истериодемоническими». К ним относили эпилепсию, бред, галлюцинации, судороги, депрессии, склонность ксамоубийству. Самым известным и распространенным было эмирячество, которым болели преимущественно женщины. Особый интерес представляют традиционные воззрения о причинах психических недугов. В статье собраны проявления разных форм психических расстройств, причин подобных заболеваний в представлениях носителей традиционной культуры и исследователей, анализируется этимология терминов.

Выявлено, что больные эмирячеством выступали как средство коммуникации божеств и духов с людьми, включая духов предков. Различные душевные недуги люди считали наказанием со стороны сверхъестественных сил. Психическое расстройство воспринималось как знак избранничества человека как будущего шамана. Высокая реалистичность образов иных миров стирала грани между земным и потусторонним мирами, формируя иллюзию их доступности. Исцелить больных могли шаманы и люди, длительно страдающие душевным недугом. Снимали психоэмоциональное напряжение посредством шаманских практик, лечебного танца, предметов, ассоцииируюихся с покоем, неподвижностью.

Ключевые слова: тюркские народы; монгольские народы; Сибирь; якуты; тувинцы; хакасы; буряты; традиционное мировоззрение; заболевание; психическое расстройство

Исследование выполнено при финансовой поддержке гранта в форме субсидии из федерального бюджета, выделяемой для государственной поддержки научных исследований, проводимых под руководством ведущего ученого (проект «От палеогенетики до культурной антропологии: комплексное интердисциплинарное исследование традиций народов трансграничных регионов: миграции, межкультурное взаимодействие и картина мира»).

\section{Для цитирования:}

Содномпилова М. М. Душевные недуги в традиционной культуре тюрко-монгольских народов Внутренней Азии: восприятие, причины, исцеление // Новые исследования Тувы. 2021, № 3. C. 249-264. DOI: https://www.doi. org/10.25178/nit.2021.3.18

Содномпилова Марина Михайловна - доктор исторических наук, исследователь лаборатории междисциплинарных исследований востоковедного профиля Калмыцкого научного центра РАН. Адрес: 358000, Российская Федерация, г. Элиста, ул. им. И. К. Илишкина, д. 8. Тел.: +7 (84722) 3-55-06. Эл. адрес: sodnompilova@yandex.ru

SODNOMPILOVA, Marina Mikhaylovna, Doctor of History, Leading Research Associate, Oriental Studies Interdisciplinary Research Laboratory, Kalmyk Scientific Center, Russian Academy of Sciences. Postal address: 8 Ilishkin St., 358000 Elista, Russian Federation. Tel.: +7 (84722) 3-55-06. E-mail: sodnompilova@yandex.ru 
Article

\title{
Mental disorders in the traditional culture of the Turkic-Mongolian peoples of Inner Asia: perception, causes, healing
}

\author{
Marina M. Sodnompilova \\ Kalmyk Scientific Center, Russian Academy of Sciences, \\ Russian Federation
}

\begin{abstract}
Among the common diseases described among the peoples of Siberia, there are various types of mental conditions, which since the 19th century have been termed «hysterical-demonic», such as epilepsy, delirium, hallucinations, convulsions, depression, or suicidal tendencies. . The most famous and widespread case was the Menerik (emiryachestvo), which mainly affected women. Of particular interest are traditional views on the causes of mental disorder. The article brings together information on various forms of such disorders and their causes as understood by people of traditional culture and by researchers. Also covered is the etymology of the terms used.

Those suffering from the Menerik were seen as a means of communication of deities and spirits with people, including the spirits of their ancestors. Various mental conditions were often considered punishment by supernatural forces or a sign that the person had been chosen as a shaman. The highly realistic imagery of the other worlds blurred the boundaries between vision and reality, creating the illusion of accessibility. Shamans and people suffering from a mental condition for a long time could heal the sick. Relief of psychoemotional stress was possible through shamanic practices, healing dance, objects associated with peace and motionlessness.
\end{abstract}

Keywords: Turkic peoples; Mongolian peoples; Siberia, Yakuts; Tuvans; Khakass people; Buryats; traditional worldview, diseases, mental disorders

\section{Financing}

The study has been supported by the federal budget subsidy for studies led by a prominent scholar (project title: "From paleogenetics to cultural anthropology: a comprehensive interdisciplinary study of traditions of cross-border regions: migrations, intercultural exchange and the world picture".

For citation:
Sodnompilova M. M. Dushevnye nedugi v traditsionnoi kul'ture tiurko-mongol'skikh narodov Vnutrennei Azii:
vospriiatie, prichiny, istselenie [Mental disorders in the traditional culture of the Turkic-Mongolian peoples of Inner
Asia: perception, causes, healing]. New Research of Tuva, 2021, no. 3, pp. 249-264. (In Russ.). DOI: https://www.doi.
org/10.25178/nit.2021.3.18

\section{Введение}

В состав распространенных заболеваний эндогенного происхождения, описываемых у народов Сибири, таких как чума, ревматизм, туберкулез, входили и разные формы душевных недугов. Распространенность таких форм заболеваний обусловлена тем, что помимо сумасшествия, в XIX в. к психическим расстройствам относили эпилепсию, бред, галлюцинации, судороги, депрессии, и склонность к самоубийству. Ненормальным объявлялся любой человек, поведение которого выходило за рамки привычной нормы. Интерес к этим заболеваниям был тесно связан с таким феноменом традиционной культуры народов Сибири как шаманизм, поскольку и причины заболеваний, и их исцеление находились в идеологии и практиках шаманизма.

Новые исследования в области психических расстройств и суицидального поведения выявляют значимость этнокультурного фактора в развитии таких форм нарушений психоэмоционального состояния человека. Это вызывает необходимость более углубленного анализа традиционного мировоззрения и культуры народов Сибири, с точки зрения их причастности к широкой распространенности душевных недугов среди якутов, тувинцев, хакасов, бурят, тесно связанных происхождением и культурой, проживающих в сходных природно-климатических условиях. 
Целью данной статьи является анализ проявлений разных форм психических расстройств, причин подобных заболеваний в представлениях носителей традиционной культуры и исследователей, а также этимологии терминов.

Для сравнения и уточнения данных привлекались материалы, характеризующие аналогичные явления у соседних народов, в частности монголов. Источниками исследования стали историко-этнографические данные, опубликованные в работах исследователей - этнографов, историков, лингвистов, фольклорные материалы.

В исследовании применялись сравнительно-исторический метод, способствующий выявлению общих черт в понимании и осмыслении причин заболеваний у тюрко-монгольских народов Сибири, а также метод культурно-исторической реконструкции, позволяющий определить логику архаических воззрений.

\section{Психические недуги в лексике тюрко-монгольских языков}

Этнографические материалы XIX в., собранные у тюрко-монгольских народов Сибири (Серошевский, 1993; Радлов, 1989; Талько-Грынцевич, 1903), описывают разные нарушения психического состояния человека, сводя большую их часть к проявлениям шаманской болезни. Исследователимедики относят их к ряду «чисто местных заболеваний нервного характера» (Рябков, 1887: 36). Самым известным и распространенным нарушением психики было эмирячество - такое название получила болезнь в языке русского населения Сибири. Позднее за данным заболеванием закрепилось название «арктическая истерия».

Термин эмирячество, вероятно, происходит от якутских слов мэнэрик - «подверженный нервным припадкам; истеричный; кликуша, кликун», мэнэрий - «биться в нервном припадке, бесноваться; кликушествовать», мэник - «шаловливый, шальной; дурной, глупый» (Слепцов, 1972: 248) и ёмюрех так якуты называли больных душевными недугами. Н. А. Виташевский считал, что «"ёмюрех" - это люди с определенным расстройством психики, легко поддающиеся внушению и гипнозу» (цит. по: Алексеев, 1975: 129). Производным этих терминов, очевидно, является слово «миряк», которым в русской среде называли мужчин, оодержимых бесом». По определению В. И. Даля, «миряки в особенности появляются в Сибири и по мнению некоторых, происходят от языческих шаманов» (цит. по: Пинтилей, Черкасова, 2013: 3).

В монгольском языке психические недуги, такие как идиотизм, слабоумие, разделяют один ряд с понятиями «тупость, глупость», «расслабление», «немощь» и даже «паралич», обозначаемыми словом мэнэг (Содномпилова, 2019: 58). Состояние, при котором человек впадал в слабоумие, передавалось терминами мэнэгтэх и мэнэгших (Большой академический ..., 2001: 372, 373). В бурятском языке присутствует слово мэнэрхэ, среди значений которого помимо «глупеть, тупеть» выделяются значения «затуманиваться», «терять чувствительность» (Бурятско-русский ..., 1973: 576). В тувинском языке известны слова-монголизмы дембээре, демээре - «бредить, нести чепуху» (Татаринцев, 2002: 126). По сведениям Е. К. Яковлева, у тувинцев, помимо легкой степени одержимости, присущей шаманам, встречались психические заболевания более тяжелой степени: «албыстан кижи, т. е. сумасшествие с редкими светлыми минутами, допускающее еще выздоровление; затем следует тэнэк - идиотизм и хальджаран - буйное, неизлечимое помешательство» (Традиционная культура ..., 2003: 62).

Известно множество диалектных обозначений психических заболеваний. Монголы душевные расстройства рассматривали как недуг женщин, одержимых бесами и злыми духами. Психические нарушения назывались адай овчин, вероятно связанных с термином, обозначающим круговой танец андай. Танец исполнялся шаманом и его помощником с участием душевнобольной пациентки и группы людей. Монголы наделяли танец андай целебной силой - верили, что он изгоняет злых духов. «Женщин и девушек, одержимых психическими заболеваниями, монголы называют андайсан, т. е. “одержимые андай” (Миягашева, 2019: 103).

Буряты южных приграничных с Монголией регионов, как и монголы, называли людей с расстройствами психики и вообще недалеких, глупых людей определением мэнэг тэнэг («идиот»). Глупых людей, и возможно больных, нередко называли ухаа дутутай («слабоумный», «придурковатый»). Более грубой версией, считавшейся оскорблением, выступало слово тэнэг («глупый», «неумный»), а также зүнтэг («выживший из ума от старости»). В шаманской лексике были известны выражения жэгтэй хүн («странный» или «необычный» человек) - «юродивый», хэдэбтэй хүн - «одержимый», человек страдавший психическим расстройством, по поверью шаманистов выполнявший волю божеств. Такие 
люди «рождаются по повелению Заян-саган-тэнгэри и должны быть ворожеями или провидцами» (Манжигеев, 1978: 51, 96). Менее распространенным является слово улуу («придурковатый», «сумасбродный», «отчаянный»). Этот термин использовали и по отношению к людям, страдающим слабоумием.

«В диалекте хоринских бурят было известно слово дунгяа (“глупый”, “придурковатый”). Повсеместно в Забайкалье употребляли слово үбшэнтэй (“больной”). Утрата хоть в какой-либо степени разумности, рассудительности, также как и слабоумие в бурятском языке выражалась также понятиями ухаа үгэй, ухаа муудалга, в котором ухаа(н) означает “ум, разум, рассудок, сознание, соображение” (Содномпилова, 2019: 59).

Термины, которыми называли разные нарушения психики, состояние утраты адекватного поведения в монгольских и тюркских языках, по мнению лингвистов, восходят к монгольскому тепеg meneng глупый, неразумный, бестолковый», монг. мэнэг «слабоумие, идиотизм», мэнэн «менингит», п.-монг. meneri - «становиться глупым, тупым, тупеть, глупеть; терять сознание, падать в обморок», монг. мэнэрэх - «отупеть, поглупеть, становиться бестолковым; терять чувствительность; падать в обморок» (Бётлинк, 1989: 612; Räsanen, 1969: 333; Рассадин, 1980: 72, 73; Аникин, 2000: 384; Татаринцев, 2008: 104).

\section{Душевные недуги в исследовательских работах XIX - начала XX в.}

Интерес к разным формам психических расстройств у населения Сибири, и, в частности, к эмирячеству, проявляли многие исследователи - врачи, чиновники, ученые. Подробные описания внешних признаков и проявления данного заболевания оставили ссыльный врач С. И. Мицкевич (Мицкевич, 1929), долгое время, работавший в Колымском округе Якутии, исследователи Г. М. Осокин, А. И. Термен - у бурят (Осокин, 1906; Термен, 1912), П. Рябков, В. Л. Серошевский, Н. А. Алексеев - у якутов (Рябков, 1887; Серошевский, 1993; Алексеев, 1975, 1980). Обращался к проблеме психических расстройств Д. К. Зеленин, рассматривая культ онгонов у народов Сибири (Зеленин, 1936). В XIX в. психические заболевания получили название «истериодемонических» и стали наиболее ранним предметом исследования ментальной этноэкологии ${ }^{1}$ (Сидоров, Медведева, Давыдов, 2014: 37).

Наиболее точные черты проявления этого заболевания были описаны С. И. Мицкевичем (Мицкевич, 1929). Он же классифицировал разные формы этого заболевания, считая их проявлением разной степени истерии. В своих наблюдениях он опирался на более ранние сведения об этом заболевании, оставленные В. Л. Серошевским (Серошевский, 1993), который очень точно охарактеризовал разные степени мэнэрика у якутов. Это заболевание выражалось

«в неудержимой склонности к подражанию всему поразившему, испугавшему или неожиданному. Слабая ее степень состоит в невольном подражании услышанным звукам или выкрикивании названия предмета, взволновавшего больного. Одержимых этой болезнью в более высокой степени можно путем постепенного раздражения довести до полузабытья, в котором они совершенно перестают владеть собой и проделывают все, что им укажут» (там же: 247).

Больных с легкой формой мэнэрика в Якутии называли «вздрагивающими» (Мицкевич, 1929: 31). Некоторыми отличиями, по мнению В. Л. Серошевского, во внешних проявлениях, характеризуется другое нервное заболевание, встречавшееся у якутов - мӓнриер. Это заболевание

«проявляется периодически, а иногда вызывается в виде отдельных припадков сильными душевными или физическими страданиями. Больной воет, кричит, причитает, рассказывает небылицы, причем часто его ломает сводит, бросает из угла в угол, пока истощившись, он не уснет. Болезни этой подвержены и девушки, но чаще женщины ${ }^{2}$, особенно страдающие женскими болезнями после замужества или несчастных родов; подвержены ей и мужчины, но редко» (Серошевский, 1993: 247-248).

С. И. Мицкевич же обозначал данное заболевание как ирер (сумасшествие) и считал ее более тяжелой, запущенной формой истерии. В якутском языке выражение мэимирер означало «мозг свертывается», русские переводили его как «ум мешается» (Мицкевич, 1929: 18).

\footnotetext{
${ }^{1}$ Сегодня это динамично развивающееся междисциплинарное направление, выступающее зоной сотрудничества этнографии, фольклористики, психологии, психиатрии, психотерапии, наркологии, ментальной медицины, ментальной экологии (Сидоров, Медведева, Давыдов, 2014: 37).

${ }^{2}$ Особую подверженность душевным недугам женщин отмечал и П. Рябков, проводивший свои исследования в Якутии: «некоторые из них [женщин] стали эмирячить только по выходе замуж... между малолетними или невкусившими запретного плода эмирячество не развито» (Рябков, 1887: 42).
} 
Проявления эмирячества у населения Забайкалья описал Г. М. Осокин, считая это заболевание подобным кликушеству (Осокин, 1906). Характерными чертами заболевания являются «причитания, вскрикивания, резкие движения, особая пугливость и повторение слов или действий другого человека» (там же: 214).

В Забайкалье буряты воспринимали это заболевание как «смешную болезнь», а больные представляли для населения объект забавы и насмешек.

«Зная непреодолимое подчинение эмиряков всем действиям и словам, часто случается, что их заставляют проделывать или говорить непристойности, драться, садиться в воду, брать горячие головни. Приходилось наблюдать, как такой больной повторял целые фразы и изречения на незнакомом ему языке. Чаще же встречаются только такие, которые скорее всего, поддаются непроизвольным действиям под влиянием минутного испуга стуком или окриком. Моменты такие долго не продолжаются и обыкновенно после двух-трех фраз больной приходит в себя, упрекая лицо, вызвавшее приступ “смешной болезни”... Нам известны некоторые эмиряки, которые сделались ими сравнительно скоро от частых шуток испугами своих ближних, причем болезнь осталась навсегда...» (там же: 215).

Аналогичным образом потешались над больными ёмюряхами якуты, «устраивая себе даровые зрелища таких вынужденных кривляний» (Серошевский, 1993: 247).

С. И. Мицкевич писал, что такие зрелища были единственным развлечением у колымчан и «пранкерами» становились все местные жители:

«Окружающие, заметив повышенную пугливость у такой женщины, начинают для забавы нарочно пугать такую “вздрагивающую” женщину. Развлечений у северного жителя мало. И местные жители от мала до велика, от захолустного якута до первого чиновника в городе (исправника, священника), по целым часам развлекаются, дразня и пугая таких “вздрагивающих”. Шутки бывают так грубы, что могли бы напугать и рассердить нормального человека и довести его до бешенства, до исступления. А как это влияет на больную женщину - истеричку!» (Мицкевич, 1929: 31).

Приведенные выше примеры общественной жизни бурят и якутов, позволяют говорить, что психические расстройства, обобщенно обозначаемые как эмирячество, в XVIII - начале XX в. были обычным явлением. Во всяком случае, в памятнике обычного права селенгинских бурят, написанном в 1775 г. есть статья № 62 об убытках и несчастных случаях вследствие нарочитого испуга и баловства, содержание которой представляет особый интерес:

«Если кто испугает действительно весьма пугливого человека и тот в испуге убьет или изувечит рядом стоящего человека или скотину или сломает вещь, то в случае убийства или увечья того, который испугал это считать его утратой, если же убьет другого человека, то штраф и наказание за это должен принять на себя испугавший человек. Если убьет какую-либо скотину или сломает вещь, то [убытки] должен возместить испугавший человек. Строго наказать [испугавшего] розгами» (цит. по: Цыбиков, 1970: 41).

Полагаем, что подобная статья в правовом документе бурят появилась неслучайно. Очевидно, что намеренный испуг психически неуравновешенного человека было частым развлечением в обществе бурят и якутов. Последствия таких действий тоже были хорошо известны, что и потребовало закрепления в законе ответственности за такие поступки. Дело, в том, что эмирячество не всегда было безвредным: по наблюдениям П. Рябкова, припадки у больных часто переходили в бешенство и тогда такой человек «становился опасным для всех, окружавших его; он хватался за топор или нож и гонялся за людьми» (Рябков, 1887: 39-40). Ситуация нередко усугублялась тем, что больной становился необычайно сильным и его трудно было удержать. Аналогичным образом описывает поведение больного В. Л. Серошевский: «Испуганный ёмюрях бросается иногда с ножом или топором на причину своего испуга» (Серошевский, 1993: 247).

Эмирячество нередко приобретало формы коллективного психоза. Как пишут исследователи, в Якутии «бывали годы, эмирячество обретало размеры эпидемии, а потом надолго ослабевало» (Рябков, 1887: 36). Формой коллективной истерии можно считать найгуры у предбайкальских бурят (религиозные шествия молодых шаманистов). Коллективный характер психических расстройств наводил на мысль о заразности этих заболеваний. В бурятском языке существовало такое понятие как дайрагдаха, что означало «заразиться психозом, возбудиться до слез и рыдания под влиянием камлания или религиозного песнопения при найгуре... Психозу подвергались фанатичные шаманисты, которые отличались психической неуравновешенностью» (Манжигеев, 1978: 42).

Свидетелем проявления групповой истерии в бурятском улусе вне религиозных событий стал Г. М. Осокин: «на посиделках группа из восьми человек потешалась над одной больной женщиной-эмирячкой, пугая ее толчками и выкриками. Но в какой-то момент неожиданно истерия 
распространилась на всех участников посиделок, а некоторых из них это состояние преследовало еще несколько дней» (Осокин, 1906: 215).

П. Рябков отмечал, что коллективные проявления эмирячества у якутских женщин приходились на вечернее время:

«Как только затопят вечерние камельки, так девушки женщины начинают эмирячить... Если в доме есть несколько сестер, то стоит только одной начать эмирячить, чтобы все начали нести всякую чепуху, да выкрикивать по-жеребьиному и проч...» (Рябков, 1887: 36);

«Нервы их вероятно уже были так настроены, что огонь камельков, резко выступавший из темноты комнаты действовал на них гипнотизирующим образом и приводил их в то состояние, при котором становилось возможным эмирячество» (там же: 42).

Обычным явлением в якутских семьях было вселение духов предков в женщин - членов семьи. Обычно они приходили к своим потомкам во время крупных религиозных праздников. По традиции богатые якутские семьи старались проводить обряд ытыкисыы - обряд посвящения лошадей божествам. Наличие священных лошадей в хозяйстве привлекало внимание божеств и предков к семье. «Если во время праздника кулун кымыса ${ }^{1}$ в семье, не имевшей коня ытык, ни одна из женщин не менерячила, то хозяева огорчались, считая, что никто из духов их не навестил, а если менерячили до 3-4 женщин сразу, то они говорили: “ну прекрасно, дали о себе знать” (Васильев, 2010: 289).

Таким образом, душевные недуги были частью повседневной жизни северян и в определенной степени были востребованы в обществе как способ коммуникации людей Срединной земли с запредельными мирами.

Главной причиной подобных групповых истерий и психических эпидемий специалисты считают нагнетание психоэмоциональной напряженности в обществе, которая «потенцирует внушаемость, самовнушаемость, аффектизацию, склонность к подражанию, паническую настроенность» (Сидоров, Медведева, Давыдов, 2014: 39).

\section{Причины психических расстройств в традиционном мировоззрении}

Причин, вызывающих психические расстройства в толковании тюрко-монгольского населения, было множество. Они были зафиксированы исследователями, пытавшимися дать объяснение такому широкому распространению данного недуга в XIX - начале XX в.

Божества и духи. В традиционном обществе любое отклонение в психике человека, его неадекватное поведение понималось как «воздействие тех или иных сил природы, а главным образом тех духов, которые этими силами заведуют» (Традиционная культура тувинцев ..., 2003: 189).

Согласно традиционным представлениям якутов, болезнь мэнэрийии вызывалась вселением в человека духов юёр или абаасы (Алексеев, 1975: 130). В якутском пандемониуме aбаahы/aбаaсы были самыми древними и исконными злыми духами Верхнего мира. На втором (снизу) верхнем небе проживало другое ужасное божество Тимир Садалбы Ойуун, от ударов бубна которого воют душевнобольные женщины (Миягашева, 2019: 103). Это небо якуты называли мӓнӓрік таххалла̄н («сумасшедшим небом»), населенным мӓнӓрік'ами, одержимыми психозами (Пекарский, 1959: 1555). В бурятском пантеоне было известно божество Бөөлур сагаан тэнгэри («Шаманящий белый небожитель»), который считался покровителем участников группового камлания (Манжигеев, 1978: 27). Кроме того, буряты-шаманисты почитали группу заянов Галзуушин ${ }^{2}$ (досл. «бешеные»), которые выступали олицетворением различных нервных и психических болезней людей (там же: 37).

Рискует потерять рассудок человек, случайно оказавшийся на пути игрищ горных духов.

«Особенно тяжело придется мирянину, уснувшему в поле на дороге горных хозяев... Окружающая их челядь забирает с собой душу человека. “Подхваченные игрой горных духов” люди теряют сознание, многие сходят с ума» (Бутанаев, 2003: 35).

С представлениями хакасов перекликаются мнения бурят о странных «болезнях девушек в возрасте», которые хворают, случайно попав в круг игрищ небесных дев. «Эти круги встречаются довольно часто в виде поросших особой зеленью кругов с южной стороны» (Жамцарано, 2001: 81). Основываясь на сведениях Ц. Жамцарано («девушки невеселы», «сохнут») (там же: 59), предполагаем, что болезни,

\footnotetext{
${ }^{1}$ Праздник рождения жеребят.

${ }^{2}$ Группа почитаемых бурятами-шаманистами духов, покровительствующих душевным недугам.
} 
которыми страдали уже взрослые девушки, скорее всего, имели отношение к нарушениям психики (депрессия, стресс).

В представлениях хакасов в качестве злого духа воспринималась айна- «невидимая отрицательная сила, негативно влияющая и дурно действующая на людей» (Бутанаев, 2006: 65), с которой первоначально люди связывали отражение человека в зеркале. «Айна пожирает людей, приносит болезни, толкает на самоубийство, преступления и другие отрицательные поступки» (там же).

Тувинцы виновным в помешательстве человека считали злого духа албыс, который нередко проникал в тело человека в результате половой связи. Состояние психически больного человека называли албыстаар (букв. «сходить с ума, бесноваться») (Тюркские народы ..., 2008: 140). Албыс становился больному как друг или любовник/ца, поэтому больной не желал называть имя албыса шаману, желавшему изгнать злого духа. После проведения ритуала изгнания албыса, исцелившемуся нельзя было приезжать на свое стойбище в течение трех лет, иначе он вновь мог заболеть (Соломатина, 1992 : $121,123)$.

Широким спектром негативных действий, в том числе и в деле распространения нервных болезней, сумасшествия, наделялись души умерших, которые становилась после смерти злыми духами. В разных культурах мнение относительно этой категории злых духов сходится - ими становятся души людей умерших прежде положенного им судьбой срока. Как раньше считали буряты, после смерти они остаются в пространстве «своего» социума и вредят сородичам, причиняя им разные болезни.

В верованиях якутов злыми духами уөр/юёр становились после смерти злые и завистливые люди, не прожившие отведенный им срок жизни (трагические погибшие, умершие в раннем возрасте, самоубийцы), погребенные с нарушениями похоронно-поминальных традиций (Якуты. Саха, 2012: 334). Духами уөр становились после смерти и некоторые шаманы (Алексеев, 1975: 136; Попов, 2008: 47). Более того, в якутском обществе имело место мнение, что уөр мог стать любой человек, если он умирал своей смертью (Васильев, 2010: 289). Вероятно, это мнение существовало в далеком прошлом якутского народа ${ }^{1}$. Якуты были убеждены, что души умерших, ставшие злыми духами уөр приносят психические болезни, особенно уөр самоубийц (Попов, 1949: 312). Многие духи уөр были знамениты и их вселение в больного можно было определить по присущим только им причитаниям.

Души умерших людей, страдавших психическими расстройствами, нередко становились причиной помешательства прежде здоровых людей и не связанных с ними родством. Подобными примерами изобилуют якутские предания. Одним из злых духов, сводившего людей с ума, был дух безумного князя Дьэллэмэя-самоубийцы (Алексеев, 2004: 310, 311). Стать сумасшедшиммог любой человек, который приобретал вещи умершего, страдавшего такой болезнью. Об этом также свидетельствует фольклор якутов. Согласно якутскому преданию, семья сошедшей с ума женщины после ее смерти продала по частям детали ее богатого конского убранства. Эти детали украсили конское снаряжение многих девушек-невест. «Девушка, снаряженная этими предметами, не жила по-человечески, говорят. Большинство сходило с ума оказывается...Когда возвращали назад [снаряжение]...то поправлялись» (там же: 312-318).

Духи входили в тело мэнэрика с целью высказывать свои требования или претензии через больного. Также через такого больного духи предсказывали будущее. Этой способностью мэнэрика часто пользовались окружающие, желая узнать будущее: «Верили, что она[больная] во время приступов, “когда в нее вселяется дьявол”, может предсказывать будущее» (Зеленин, 1936: 362). В свою очередь, возможность попросить что-либо от имени дьявола, особенно спирт, была соблазнительна для многих, что побуждало их представляться больными. В итоге, в результате регулярных «упражнений» по изображению больного, здоровый человек пополнял число душевно больных.

Сходное явление, которое можно обозначить как вселение духа в тело человека онгоруулха, онготохо широко встречалось у бурятских шаманистов. А. И. Манжигеев писал, что в такое необычное состояние, при котором человек приходил в нервное возбуждение, пел, плясал, либо говорил от имени вселившегося в него духа, приходили люди, страдающие какой-либо хронической болезнью, либо в состоянии аффекта (Манжигеев, 1978: 64). Другим, менее известным термином в бурятском языке, описывающем нисхождение почитаемого духа на душу шаманиста, является термин дайрагдаха, о котором говорилось выше.

1 «По поверьям якутов естественная смерть считалась зазорной, так как душа покойника не попадала в загробный мир, а превращалась в злого духа. Поэтому в старину соблюдался обычай добровольной смерти» (Васильев, 2010: 288). 
По представлениям хакасов, душевный недуг является проявлением брака человека с горным духом. «Если душевно заболела девушка, то значит она вышла замуж за горного духа, если парень - то имеет горную жену» (Бутанаев, 2003: 34).

В якутском обществе к числу психически нездоровых людей нередко причисляют певцов и сказителей. Якуты верили, что в процессе исполнения песен и эпоса, певец или сказитель пребывают в особом состоянии, когда у них «раскрывается плоть» - «его устами начинали говорить духи, предсказывая предстоящие события в жизни, как рода, так и отдельных людей» (Бравина, 2005: 120).

Особый интерес в этой связи вызывает образ такого человека в традиционных представлениях тюрко-монголов.

Мнения бурят и хакасов в отношении того, каким должен быть такой человек совпадают: буряты характеризуют его как «чистого» человека, нередко имеющего белое шаманское происхождение. Об одном из таких людей писал М. Н. Хангалов:

«Ямщик наш был бурят и калека...Наш ямщик был работником у одного бурята и в это время начал делаться одержимым. Имел он белое шаманское происхождение и поэтому ему нельзя было дотрагиваться до нечистых предметов. Однажды во двор его хозяина из соседнего села пришли свиньи, которых наш ямщик хотел ударить. Взяв в руки палку, он ударил одну из них. Как только он ударил свинью, то сразу упал в обморок, из носу и изо рта у него пошла кровь, отнялись руки и ноги, потому что он сделался нечистым. Тогда шаман Манжу сделал над ним очистительное и освящающее теломытие и только тогда он выздоровел, но остался калекой» (Хангалов, 1959: 152).

Хакасы легко поддающихся внушению, гипнозу людей тоже характеризуют как арыг - «чистого, святого, со сверхъестественными задатками, с шаманским даром (букв. “с чистой костью”); считалось, что это «подвижный человек с легкой костью, легко впадающий в транс» (Бутанаев, 1999: 27). Им противопоставляются люди с «тяжелой костью» или «тяжелой породы». Очевидно, что под «тяжелой костью» подразумевалась устойчивость психического состояния человека, поскольку обладатель «тяжелой кости» не поддается гипнозу. Крайне любопытны взгляды о связи психики человека с костью, отраженные в хакасском выражении «кость облегчается», что означает утрату разума (там же: 120). Вероятно, хакасы связывали такие понятия как «разум», «сознание» с состоянием костного мозга. Однако, в тюрко-монгольских языках более известны соотношения понятий «разум», «сознание», «психика» с душой человека. В этой связи уместно вспомнить традиционное восприятие костей, особенно мозговых, как вместилища сульдэ, кут (жизненная субстанция, душа) человека в мировоззрении тюрко-монгольских народов (Содномпилова, Нанзатов, 2020: 210). С этих позиций связь между костью и разумом в хакасском выражении не выглядит невероятной.

Утрата души. Среди народов Сибири бытует мнение, что к лишению разума могла привести утрата человеком души

Такие последствия потери души фиксируются в материалах, собранных В. И. Вербицким у алтайских народов - человек, лишенный души, терял память и сознание (Вербицкий, 1893: 78), В. М. Кулемзиным у хантов - потерей номыс, т. е. ума/души объясняли сумасшествие восточные и северные ханты (Кулемзин, 1984: 127).

Эти взгляды разделяют и тувинцы, в верованиях которых человек обладает разными душами: если человек лишается сунези, оставаясь с одной животной душой тын, то он лишается памяти и сознания (Дьяконова, 1975: 48). Таким же образом объясняется умопомешательство шамана в якутской традиции: душа шамана похищалась злыми духами и находилась у них на воспитании (Алексеев, 1975: 131).

Предки-шаманы. Разные формы психического недуга в большинстве случаев исследователями сводились к «шаманской болезни». В традиционном мировоззрении ее причиной были духи предковшаманов, которые овладевали душой человека и побуждали его стать шаманом.

«До сих пор в народе говорят, что всякий хороший шаман, т. е. обладающий ясновидением, действительным общением с духами, страдающий припадками, непременно происходит от какого-нибудь знаменитого шамана, дух которого в него переходить; что есть целые семьи, в которых все почти члены становятся шаманами. В этом убеждении больше истины, чем можно было бы ожидать. Привычка возбуждать свои нервы силою самовнушения может легко перейти в психическое расстройство, которое и передается потомству в форме эпилепсии» (Термен, 1912: 22).

\footnotetext{
${ }^{1}$ У тюрко-монголов более распространенным является мнение, что лишившийся души человек в скором времени умрет.
} 
В процессе своего становления шаман овладевал искусством управления духами. Главное отличие шамана от больного мэнэрика, в которого также вселялся дух, состоит в том, что «шаман входил в контакт с духами добровольно и сознательно и будучи в экстазе полностью контролировал ситуацию, направляя “разговор” с духами в нужное для него русло» (Бравина, 2005: 121), а телом больного мӓнӓріi/ мэнэрийэр (Пекарский, 1959: 1554) духи овладевали против его воли. Шаман также мог стать мэнэриком, но только в том случае, если «другой, более сильный шаман напустит на него дух, и он не властен над этим духом» (Мицкевич, 1929: 14).

А. А. Попов объяснял неуязвимость сильных/настоящих шаманов для духов наличием у них в теле «особого помещения в животе»- киэли, предназначенного для духов. Находясь там, духи не могут причинить вред шаману. Простые люди, больные мэнэрийэр, не имеющие киэли, погибнут, поскольку злой дух, забравшийся к ним в живот, не сможет покинуть тело (Попов, 2008: 42).

Тувинцы были убеждены, что потомок именитых шаманов, который не хотел продолжать дело своих предков, ощущал их зов всем телом: отдаленные звуки бубна приводили его в дрожь, затем начинались подергивания, переходившие в кривляние; глаза его разгорались, он начинал метаться и дурить. В такое же состояние впадал и тот, кто прекращал шаманскую практику по собственному желанию. Тот же, кто получил необычайный дар, но не смог освоить шаманское ремесло, тоже сходил с ума (Монгуш, 2012: 298).

К потере рассудка могли привести акты вандализма по отношению к предметам религиозных культов, например осквернение предметов шаманского культа, повреждение или рубка деревьев в священных шаманских рощах (метах захоронения шаманов). Верили, что таковым было наказание шаманских духов. Однако, подобное же наказание ожидало любого, кто осквернял и буддийские реликвии. В период активной антирелигиозной пропаганды, пришедшейся на начальный период становления советской власти, многие молодые люди, бросая вызов прошлому, совершали недостойные поступки - рушили храмы, сжигали священные книги. В Бурятии известно множество историй, повествующих о комсомольцах, наказанных душевными недугами за непочтительное отношение к буддийским реликвиям. Так, например, психическим расстройством заболела девушка-комсомолка, использовавшей в качестве платка ткань, в которую заворачивали буддийскую книгу. «Внезапно она стала разговаривать на непонятном языке и утверждать, что она книга. Недуг прошел, как только по совету ламы семья девушки совершила необходимый обряд» (Цыденова, 2009: 172).

Иные причины. Среди причин, вызывавших расстройство психики у населения Сибири, следует указать природные и климатические факторы. В XIX-XX вв. они занимали важное место в объяснении медиками причин «истериодемонических» заболеваний в Сибири и на Севере. Их мнение разделяли и этнографы: длительный холодный период, однообразие полярной зимы в северной части Сибири считался одним из фактором, угнетающих психику (Гурвич, 1977: 113). В начале ХХ в. к числу природных причин психических расстройств у русского населения Забайкалья, известный исследователь Ю. Д. Талько-Грынцевич отнес грозовые явления. Ученый занимался исследованием природы нервных заболеваний и физиологических особенностей организма женщин - казачек, старожилок и семейских. По его убеждению, «сильные ветры в вечернее и ночное время, летние бури и грозы наводят страх на девушек и женщин, отчего те подвержены беспокойству вплоть до истерики» (Талько-Грынцевич, 1903: 99).

Причина психического расстройства в природных явлениях обнаруживается и в традиционном мировоззрении тюрко-монголов. Так, в частности тувинцы, полагали, что привести к нервному потрясению могла радуга. Тувинцы были убеждены, что после грозы радуга, застигшая человека в степи, может ударить его одним концом и в него тогда вселяется дух умершего шамана. «Это настолько обычное явление, что после каждой грозы сойоты выезжали в степь на поиски не возвратившихся до грозы сородичей» (Кон, 1936: 45).

Ф. Я. Кон сам выезжал на поиски такого пропавшего и застал его, бившегося в падучей (так в прошлом называли эпилепсию). Эту болезнь тувинцы называли «небесной болезнью» или «содроганием». Заболеть ею можно было и от родника: «в маловодных ключиках во время смены погоды непогодой, в местах, где в камнях брошен труп человека, подымается ветер, вызываемый “хозяином” этого ключика. На кого подует этот ветер, тот и начинает страдать падучей» (там же: 46).

Если одни видели в «ударе» радуги причину душевной болезни, другие верили, что это величайший дар неба. Как удалось выявить Г. Е. Грумм-Гржимайло, великие тувинские шаманы свою высшую силу получают с соизволения Неба: «проходит темная туча, появляется радуга, ударяет своим концом по 
человеку и вселяет в него эту силу» (Традиционная культура тувинцев ..., 2003: 127). Под этой силой подразумевается душа умершего великого шамана. Со временем, перерождаясь в своих потомках (т. е. обычным способом) душа шамана утрачивает свою силу-так объясняли тувинцы исчезновение в $\mathrm{XX}$ в. могущественных шаманов.

Таким образом, в традиционном мировоззрении тюрко-монгольских народов Сибири все разнообразие причин душевных недугов сводится к воздействию сверхъестественных сил, персонифицированных в образе божеств и духов, и «шаманской» болезни, вызываемой предками-шаманами, стремящимися возродиться в своих потомках.

Суицид. Одной из форм психических расстройств была склонность к суициду. Очевидно, что попытки самоубийства были нередки в монгольском обществе XVIII в. Об этом можно судить на основании статьи закона, представленного в памятнике монгольского права «Восемнадцать степных законов»: «Кто окажет помощь в спасении человека, пытающегося повеситься... тот должен получить коня» (Восемнадцать степных ..., 2002: 146).

В конце XIX - начале XX в. ситуация с самоубийствами усугубилась среди бурят в Иркутской губернии. Этой проблеме в своей работе особое внимание уделил А. И. Термен (Термен, 1912: 126). В этом же ведомстве имело место быть коллективное самоубийство нескольких девушек во главе с известной красавицей Буржуутхайн-дуухэй, насильно выданной замуж. После смерти они стали почитаемыми духами, а их количество за счет новых самоубийц и трагически погибших женщин регулярно росло, достигнув 360 чел. K их сонму причисляли и женщин, находившихся в родстве с Буржуутхайн-дуухэй (Небесная дева-лебедь, 1992: 285).

Подобные предания легли в основу множества художественных произведений и театральных постановок, таких как тувинская пьеса «Хайыраан боот», основанная на народной легенде «Хүн көрбес» (Солнце не видящая) (Херел, 2015), бурятская пьеса «Улейские девушки».

По представлениям бурят, к суициду человека подталкивают зловредные духи. Известное предание молькинских бурят о злых духах, подталкивающих людей к самоубийству, было записано М. Н. Хангаловым со слов Луки Аршинова (Хангалов, 1959: 12). В верованиях хакасов негативная сверхъестественная сила, приводящая людей к суициду, персонифицировалась в образе особого духа поончах. Он входил в число шаманских тёсей и обитал в среднем мире по берегам рек, среди чернотала.

Сходные представления о местопребывании злых духов существовали и у кумандинцев. По их мнению, злые духи узюты обосновывались в густых зарослях осинника и тальника (Традиционное мировоззрение ..., 1989: 107). Уничтожить духа суицида могли хакасские шаманы. Они сбрасывали его в ручей, уходящий под землю - «родник без устья». «Люди боялись подобных мест, не пользовались этой водой, а детям запрещали там играть и купаться» (Бутанаев, 2006: 123). Хакасы верили, что дух поончах мог быть опасен для любого человека с самого рождения, особенно в семьях, где уже бывали случаи самоубийства. Поончах как будто бы программировал «суицидальное» поведение. В «профилактических» целях ребенку при рождении проводили обряд «разрезания петли». Избавить от зловредного духа могли только шаманы (Бурнаков, 2005).

Склонность к самоубийству среди якутов объясняется с позиций реалистичности загробной жизни в традиционном мировоззрении якутов. «Самоубийство люди рассматривали как добровольный переход в другой, подобный мир» (Гурвич, 1977: 141). Такое объяснение подтверждается материалами якутского фольклора. Мифологические и исторические предания якутов показывают, что якут жил в особом мире, в котором сверхъестественное сосуществует с человеком, а пути в иные миры доступны многим, а не только шаманам. Таким местами - «священными» и «нечистыми» - изобилует все пространство, освоенное якутами (Бравина, 2005: 25). Близость и доступность иных миров, их реалистичность, в определенной степени и стала причиной распространенности суицидальных настроений в якутском обществе. Для якутов иные миры - это реально существующие пространства, где люди могут встретиться с божествами, предками, недавно умершими людьми. Там они могут завершить начатые в земном мире дела. Так, один из персонажей якутских преданий Кутаахаан позволяет врагам расправиться с собой, чтобы предстать перед судом божеств и доказать свою невиновность (Алексеев, 2004: 287-290). В других якутских преданиях герои, спеша поделиться хорошей вестью со своими умершими родственниками, не задумываясь, заканчивали жизнь самоубийством (Гурвич, 1977: 150-157). Уместно напомнить в этой связи и отношение якутов к естественной смерти, которая считалась недопустимой.

Огромное влияние на рост самоубийств в среде хакасов в середине XX в. оказала усилившаяся вера в легкую безмятежную жизнь в ином мире: «Люди верят, что человек здесь, в нашем мире, находится 
временно, а жизнь его в том мире - постоянная; что здесь, в нашем мире, много всяких трудностей, трудно жить, а там жить хорошо и без труда» (Бурнаков, 2005: 55).

Менее яркими красками рисовалась жизнь в загробном мире в традиционных представлениях бурят-шаманистов. В мировоззрении бурят обнаруживается большое число версий загробного мира, которые не поддаются какой-либо логичной классификации (уленши - местопребывание мастеров, рай для воинов, жизнь на небе, среди небожителей, которая была уготована некоторым шаманам и шаманкам и др.). Для большинства умерших жизнь в ином мире мало чем отличалась от земной, и, хотя жить там было легче (одежда не изнашивалась, всегда была пища, не было изнурительной работы), немногие желали осознанно покинуть подсолнечный мир. Важно отметить и негативное отношение бурят к самоубийцам, души которых становились изгоями в потустороннем мире. Большинство их было обречено скитаться среди живых и причинять им разные козни. Самоубийц не хоронили на родовых кладбищах, их имена забывались, шаманы при совершении обрядов их не почитали и прогоняли. Мало кто из самоубийц находил оправдание у бурят и возводился в ранг почитаемых духов. «Хотя бурят и видит в смерти переход к лучшей жизни, но самой смерти страшно боится и при жизни особенно следит за всем тем, что, по его мнению, могло бы вызвать преждевременную смерть» (Осокин, 1906: 221). Существенное влияние на понимание сущности жизненного пути оказал буддизм, особенно его концепция о перерождении души, которая придала высокую ценность жизни в человеческом облике. Поэтому, к самоубийству людей все же подталкивали безысходность, горе, несчастья и злоупотребление спиртными напитками.

Известные этнографические материалы о случаях суицида, собранные у народов Сибири, показывают, что наиболее распространенным способом самоубийств является повешение. Нередко в описании образов злых духов, подталкивающих людей к самоубийству, упоминается веревка, которую дух держит в руках. В хакасских обрядах, направленных на избавление людей от таких духов имитируется тело человека с веревкой на шее (Бутанаев, 2003: 95), другой обряд носит название «разрезание петли». Своеобразные представления и действия по отношению к самоубийцам отложились в традиционной культуре якутов. Согласно якутским преданиям, повесившийся человек оставался живым, пока была цела веревка - она соединяла его с миром живых. Веревку самоубийцы следовало развязать - якуты верили, что тогда человека можно было спасти. Обрезание веревки у повесившегося было равнозначно «прерыванию его дыхания», т. е. убийству (Алексеев, 2004: 317, 319).

Исцеление. Приемы исцеления больных психическими расстройствами в народной целительской практике были разными. Распространенным способом было лечение больных в водах целебных озер, которые «помогали» и в лечении заболевших бешенством людей и животных.

Подобных целебных озер в пространстве этнической Бурятии было несколько. Больные «шаманской болезнью» исцелялись либо временно облегчали течение заболевания в процессе шаманских практик. Считалось также, что хорошо помогают предметы, которые ассоциировались с неподвижностью, покоем. Тофалары, например, для успокоения буйного человека вшивали тайно от него в рукав одежды кусочек веревки, которой были связаны руки и ноги покойника (Алексеев, 1980: 57). Тувинцы особо ценили растение «Марьин корень», который считали полезным при заболеваниях нервной системы, как успокаивающее средство для «возбужденных людей» (Даржа, 2009: 317). Якуты считали спасительным средством исцеления от сумасшествия

«переход через каменистый ручей с бурным течением. Злые духи, испугавшись быстрой воды, отставали от своих жертв. Так духи-хозяева родной земли оберегают, охраняют своих обитателей» (Бравина, 2005: 26).

В основном, излечить страдающих психическим расстройством, т. е. избавить от злого духа, досаждающего больному могли шаманы. Кроме шаманов помочь таким больным, по мнению якутов могли старые мэнэрики, хронически страдающие этой болезнью (Алексеев, 1975: 130).

Монголы считали, что больной может вылечиться посредством танца андай. Танцем и группой лиц, принимавших участие в процессе исцеления больных, руководил шаман (Миягашева, 2019: 103). Буряты полагали, что исцелению больных, страдающих расстройством психики, способствует найгур ${ }^{1}$.

Нередко душевные недуги оставляли больного, прекращаясь сами по себе. «Бывали также случаи, что одержимые эмирячеством излечивались навсегда после какого-либо особенно сильного нервного потрясения, как например сильного горя, страха, трудной болезни» (Осокин, 1906: 215).

\footnotetext{
${ }^{1}$ Буряты считали, что попавшие под влияние найгура (религиозное шествие молодых шаманистов, в целях признания культа нового духа-покровителя (Манжигеев, 1978: 59; Михайлов, 1987: 281) молодые люди, впоследствии в процессе хождений и песнопений успокаивались и возвращались в свое обычное состояние.
} 
Отмечается тот факт, что на усиление или ослабление недугов влияние оказывали разные сезоны года. Среди тюрко-монгольских народов Внутренней Азии бытует мнение, что душевная болезнь начинает обостряться весной, после первого крика кукушки. Осенью, как только замерзнут реки, больные успокаиваются и опять ведут себя нормально (Бутанаев, 2003: 34).

Приемы исцеления от душевных недугов преимущественно соотносятся с практиками шаманов. Кроме того, «помогают» в лечении водные источники, некоторые растения.

\section{Заключение}

Рассмотренный в статье массив этнографических, исторических, фольклорных, лингвистических материалов показывает, что психические расстройства были обыденным явлением в жизни населения Сибири. Легкие формы душевных недугов не считались болезнью, другие формы понимались как проявления воли духов, «шаманская болезнь». Правомерно считать, что эти заболевания в какой-то степени были адаптационным ответом человека на негативные вызовы со стороны природы, общества, государства. Человек традиционного общества жил в вечном страхе за свою жизнь и жизнь своих потомков. Ему угрожали воинственные соседи и природа в лице опасных погодных явлений, животных, болезней, а также целая армия воображаемых божеств и духов. Суровые требования, выдвигаемые традиционным обществом по отношению к женщине, представляли большой комплекс запретов и ограничений, которые объясняют расстройство психики преимущественно у женского населения. Эмирячество у женщин обуславливалось расстройством половой системы, неблагополучными родами. К этому выводу пришли исследователи-медики XIX - начала XX в. В исследованиях XX-XXI вв. была подтверждена особая роль в развитии эмирячества традиционной духовной культуры коренного населения Сибири и Севера, в частности традиций шаманизма.

На наш взгляд, усугубляла психическое состояние населения и изоляция, которая проистекала из особой формы ведения скотоводческого хозяйства - семья проживала зимой практически в одиночестве на зимниках, отдаленных заимках. Многие люди и особенно женщины никогда не бывали за пределами своего постоянного места проживания. Подобный образ жизни отражался и на характере людей. «Якуты, проживающие в верховьях или у истоков небольших рек полушутя говорили о себе, что они “молчаливее рыбы, замкнутее яйца” (Бравина, 2005: 11). Такие условия жизни постоянно поддерживали высокий уровень психоэмоционального напряжения в обществе. Ситуация осложнялась и рядом экзогенных факторов - низкой культурой, голодом, нищетой, алкоголем, болезнями.

В целом, длительные исследования специфичных заболеваний психики, называемых истериодемоническими у населения Сибири и Севера, позволили определить большой круг эндогенных и экзогенных факторов, влияющих на формирование, развитие и распространение заболеваний. Современные исследования в области психического здоровья одну из причин повышенной склонности к самоубийству среди якутов, бурят, тувинцев, эвенков видят в культурно-специфических особенностях когнитивных функций, в частности в сниженной подвижности психических процессов, а также склонности к чрезмерной генерализации, субъективном ощущении неразрешимости жизненных трудностей (Семенова, 2019: 29). Другой причиной считают низкую стрессоустойчивость, вызванную зависимостью от социальной оценки, чувство вины и стыда, скрытность (Семке, Богомаз, Бохан, 2012: 94-98).

\section{СПИСОК ЛИТЕРАТУРЫ} 200 c.

Алексеев, Н. А. (1975) Традиционные религиозные верования якутов в XIX - начале XX в. Новосибирск : Наука.

Алексеев, Н. А. (1980) Ранние формы религии тюркоязычных народов Сибири. Новосибирск : Наука. 315 с.

Алексеев, Н. А. (2004) Якутские мифы. Новосибирск : Наука. 451 с.

Аникин, А. Е. (2000) Этимологический словарь русских диалектов Сибири. Новосибирск : Наука. 772 с.

Большой академический монгольско-русский словарь (2001): в 4 т. / отв. ред. Г. Ц. Пюрбеев. М. : ACADEMIA. T. II. $536 \mathrm{c.}$

Бравина, Р. И. (2005) Концепция жизни и смерти в культуре этноса на материале традиций саха. Новосибирск : Наука. 307 с.

Бётлинк, О. Н. (1989) О языке якутов. Новосибирск : Наука. 644 с.

Бурятско-русский словарь (1973) / сост. К. М. Черемисов. М. : Советская энциклопедия. 803 с. 
Бурнаков, В. А. (2005) Суицид и традиционное мировоззрение хакасов. Из архивных материалов КГБ // Проблемы археологии, этнографии, антропологии Сибири и сопредельных территорий. Т. ХІ. Ч. II. С. 52-56.

Бутанаев, В. Я. (1999) Хакасско-русский историко-этнографический словарь. Абакан : Хакасия. 235 с.

Бутанаев, В. Я. (2003) Бурханизм тюрков Саяно-Алтая. Абакан : Изд-во Хакасского государственного университета. 260 с.

Бутанаев, В. Я. (2006) Традиционный шаманизм Хонгорая. Абакан : Изд-во Хакасского государственного университета. 254 с.

Васильев, В. Е. (2010) Обряд посвящения ытык как сакральный договор с божествами верхнего мира // Этногенез и культурогенез в Байкальском регионе (средневековье) / отв. ред. П. Б. Коновалов, Е. Н. Романова. Улан-Удэ: Изд-во БНЦ СО РАН. 410 с. С. 274-292

Вербицкий, В. И. (1893) Алтайские инородцы. Сборник этнографических статей и исследований. М. : Скоропеч. А. А. Левенсон. 221 с.

Восемнадцать степных законов. Памятник монгольского права XVI-XVII вв. (2002) / пер. монг. текста, ком. и исс. А. Д. Насилова. СПб. : Петербургское востоковедение. 159 с.

Гурвич, И. С. (1977) Культура северных якутов-оленеводов. М. : Наука. 245 с.

Даржа, В. К. (2009) Традиционные мужские занятия тувинцев. Т. 1. Хозяйство, охота, рыбалка. Кызыл : Тувинское книжное изд-во. 589 с. 163 с.

Дьяконова, В. П. (1975) Погребальный обряд тувинцев как историко-этнографический источник. Л. : Наука.

Жамцарано, Ц. (2001) Путевые дневники 1903-1907 гг. Улан-Удэ : Изд-во БНЦ СО РАН. 380 с.

Зеленин, Д. К. (1936) Культ онгонов в Сибири. Пережитки тотемизма в идеологии сибирских народов. М.; Л.: Наука. 436 с.

Кон, Ф. Я. (1936) За пятьдесят лет. 2-е изд. Т. 3-4. М.: Советский писатель. 344 с.

Кулемзин, В. М. (1984) Человек и природа в верованиях хантов. Томск : Изд-во Томского университета. 187 с.

Манжигеев, И. А. (1978) Бурятские шаманистические и дошаманистические термины. Опыт атеистической интерпретации. М.: Наука. 125 с.

Михайлов, Т. М. (1987) Бурятский шаманизм: история, структура и социальные функции. Новосибирск: Наука. 282 c.

Мицкевич, С. И. (1929) Мэнэрик и эмиряченье. Формы истерии в Колымском крае. Л. : Изд-во Академии наук СССР. 53 с.

Миягашева, С. Б. (2019) Семантика ритуального лечебного танца андай у монгольских народов // Вестник Бурятского научного центра Сибирского отделения Российской академии наук. № 3 (35). C. 102-109. DOI: https:// www.doi.org/ 10.31554/2222-9175-2019-35-10-102-109

Монгуш, М. В. (2012) Шаманизм и неошаманизм в Туве // Ученые записки. Вып. ХХІІІ. Тувинский институт гуманитарных исследований. Кызыл: Тываполиграф. 612 с. С. 297-321

Небесная дева-лебедь. Бурятские сказки, предания и легенды (1992) / сост. И. Е. Тугутов, А. И. Тугутов; пер. А. И. Тугутов; комм. И. Е. Тугутов, А. И. Тугутов, Л. Н. Нуркаева. Иркутск : Восточно-Сибирское книжное издание. 368 c.

Осокин Г. М. (1906) На границе Монголии. Очерки и материалы к этнографии юго-западного Забайкалья. СПб. : Типография А.С. Суворина. 214 с.

Пекарский, Э. К. (1959) Словарь якутского языка : в 3 т. 2-е изд. М. : АН СССР. Т. ІІ. Вып. 5-9. стб. 1281-2508. 641 с.

Пинтилей, Н. В., Черкасова, Е. С. (2013) Этиология и традиционные методы лечения психических заболеваний в русской народной медицине [Электронный ресурс] // Медицина и образование в Сибири. № 4. URL: http://ngmu. $\mathrm{ru} / \mathrm{cozo} / \mathrm{mos} /$ article/abauthors.php?id=1040 (дата обращения: 05.06.2021).

Попов, А. А. (1949) Материалы по истории религии якутов бывшего Вилюйского округа // Сборник музея археологии и этнографии. Т. ХІ. 394 с. С. 257-323.

Попов, А. А. (2008) Камлания шаманов бывшего Вилюйского округа: тексты. 2-е изд. / сост. Р. И. Бравина. Новосибирск : Наука. 464 с.

Радлов, В. В. (1989) Из Сибири. Страницы дневника. М. : Наука; Главная редакция восточной литературы. 749 с.

Рассадин, В. И. (1980) Монголо-бурятские заимствования в сибирских тюркских языках. М. : Наука. 116 с.

Рябков, П. (1887) Полярные страны Сибири (заметки и наблюдения в Колымском округе) // Сибирский сборник / под ред. Н. М. Ядринцева. Вып. 1887. СПб. : Типография И. Н. Скороходова. 278 с. С. 1-42.

Семенова, Н. Б. (2019) Предпосылки суицидального поведения у детей и подростков коренных народов Сибири: когнитивные факторы риска. Часть II // Суицидология. Т. 10. № 3 (36). С. 19-31.

Семке, В. Я., Богомаз, С. А., Бохан, Т. Г. (2012) Качество жизни молодежи народов Сибири как системный показатель уровня стрессоустойчивости // Сибирский вестник психиатрии и наркологии. № 2 (71). С. 94-98. 
Серошевский, В. Л. (1993) Якуты. Опыт этнографического исследования. М. : Московская типография № 2.736 с.

Сидоров, П. И., Медведева, В. В., Давыдов, А. Н. (2014) Истериодемонические истоки психических эпидемий // Психическое здоровье. № 4. С. 39-48.

Слепцов, П. А. (1972) Якутско-русский словарь. М. : Изд-во Советская энциклопедия. 568 с.

Содномпилова, М. М. (2019) Между медициной и магией: практики народной медицины в культуре монгольских народов (XVII-XIX вв.). М. : Восточная литература. 205 с.

Содномпилова, М. М., Нанзатов, Б. 3. (2020) «Костная» версия антропоморфной модели в традиционном мировоззрении тюрко-монголов Внутренней Азии: образы, значение, функции // Вестник археологии, антропологии и этнографии. № 4 (51). С. 207-217. DOI: https://www.doi.org/ 10.20874/2071-0437-2020-51-4-18.

Соломатина, С. Н. (1992) Материалы по шаманству у тувинцев // Материалы полевых этнографических исследований 1988-1989 гг. / отв. ред. Ю. Ю. Карпов. СПб. : Наука. Вып. 1. 180 с. С. 119-129.

Талько-Грынцевич, Ю. Д. (1903) К вопросу об изучении физиологических явлений половой жизни женщин в Забайкалье // Труды Троицкосавско-Кяхтинского отделения Приамурского отдела Имп. Русского географического общества. СПб : Типо-литография Герольдт. Т. VI. Вып. 1. 172 с. С. 95-135.

Татаринцев, Б. И. (2002) Этимологический словарь тувинского языка. Новосибирск : Наука. Т. II. 387 с.

Татаринцев, Б. И. (2008) Этимологический словарь тувинского языка. Новосибирск : Наука. T. IV. 442 с.

Термен, А. И. (1912) Среди бурят Иркутской губернии и Забайкальского края. Очерки и впечатления. СПб. : Типография Министерства Внутренних Дел. 144 с.

Традиционное мировоззрение тюрков Южной Сибири: Человек. Общество (1989) / Э. Л. Львова и др. Новосибирск : Наука. 243 с.

Традиционная культура тувинцев глазами иностранцев (конец XIX - начало XX века) (2002) / подг. текстов, предисл. и комм. А. К. Кужугет. Кызыл : Тувинское книжное издательство. 224 с.

Тюркские народы Восточной Сибири (2008) / отв. ред. Д. А. Функ, Н. А. Алексеев. М. : Наука. 422 с.

Хангалов, М. Н. (1959) Собрание сочинений : в 3 т. Улан-Удэ : Бурятское книжное изд-во. Т. II. 442 с.

Херел, А. Х. (2015) Преломление жанра народной легенды в тувинской драматургии (на материале пьесы «Хайыраан боот») В. Кок-оола // Вестник Бурятского государственного университета. Вып. 10(1). С. $249-255$.

Цыбиков, Б. Д. (1970) Обычное право селенгинских бурят. Улан-Удэ : Бурятское книжное изд-во. 282 с.

Цыденова, Д. Ц. (2009) Представления агинских бурят о жизни и смерти. Новосибирск : Редакционноиздательский центр НГУ. 193 с.

Якуты. Саха (2012) / отв. ред. Н. А. Алексеев и др. М. : Наука. 599 с.

Räsanen, M. (1969) Versuch eines etymologisches Wörterbuch der Türksprachen. Helsinki. 533 p.

Дата поступления: 06.06.2021 2.

\section{REFERENCES}

Alekseev, N. A. (1975) Traditsionnye religioznye verovaniia iakutov $v$ XIX - nachale XX v. [Traditional religious beliefs of the Yakuts in the $19^{\text {th }}$ and early $20^{\text {th }}$ century]. Novosibirsk, Nauka. 200 p. (In Russ.)

Alekseev, N. A. (1980) Rannie formy religii tiurkoiazychnykh narodov Sibiri [Early forms of religion of the Turkic peoples of Siberia]. Novosibirsk, Nauka. 318 p. (In Russ.).

Alekseev, N. A. (2004) Yakutskie mify [Yakut myths]. Novosibirsk, Nauka. 451 p. (In Russ.)

Anikin, A. E. (2000) Etimologicheskii slovar' russkikh dialektov Sibiri [An etymological dictionary of Russian dialects of Siberia]. Novosibirsk, Nauka. 772 p. (In Russ.)

Bol'shoi akademicheskii mongol'sko-russkii slovar' [The grand academic Mongolian-Russian dictionary] (2001b): in 4 vols. / executive editor G. Ts. Piurbeev. Moscow, Academia. Vol. 2. 536 p. (In Russ.)

Bravina, R. I. (2005) Kontseptsiia zhizni i smerti v kul'ture etnosa na materiale traditsii sakha [The concept of life and death in the culture of an ethnic group: the case of the Sakha traditions]. Novosibirsk, Nauka. 307 p. (In Russ.)

Betlink, O. N. (1989) O iazyke iakutov [About the Yakut language]. Novosibirsk, Nauka. 644 p. (In Russ.)

Buriatsko-russkii slovar' [A Buryat-Russian dictionary] (1973) / comp. by K. M. Cheremisov. Moscow, Sov. entsiklopediia. 803 p. (In Russ.).

Burnakov, V. A. (2005) Suitsid i traditsionnoe mirovozzrenie khakasov. Iz arkhivnykh materialov KGB [Suicide and the traditional worldview of the Khakas. From the materials of the KGB archive]. Problemy arkheologii, etnografi, antropologii Sibiri i sopredel'nykh territorii, vol. XI, part II, pp. 52-56.

Butanaev, V. (1999) Khakassko-russkii istoriko-etnograficheskii slovar' [A Khakas-Russian historical and ethnographic dictionary]. Abakan, UPP Hakasiya. 240 p. (In Russ.).

Butanaev, V. Ya. (2003) Burkhanizm tiurkov Saiano-Altaia [Burkhanism of the Sayano-Altai Turks]. Abakan, Publishing House of Khakass State University. 260 p. (In Russ.). 
Butanaev, V. Ya. (2006) Traditsionnyi shamanizm Khongoraia [Traditional Shamanism in Hongorai]. Abakan, Publishing House of Khakass State University. 254 p. (In Russ.)

Vasil'ev, V. E. (2010) Obriad posviashcheniia ytyk kak sakral'nyi dogovor s bozhestvami verkhnego mira [Ytyk, the rite of initiation, as a sacred contract with the deities of the upper world]. In: Etnogenez i kul'turogenez v Baikal'skom regione (srednevekov'e) [Ethnogenesis and cultural genesis in the Baikal region in the Middle Ages] / ed. by P. B. Konovalov and E. N. Romanova. Ulan-Ude, BNTs SO RAN Publ. 410 p. Pp. 274-292. (In Russ.)

Verbitskii, V. I. (1893) Altaiskie inorodtsy. Sbornik etnograficheskikh statei i issledovanii [Non-Russian peoples of the Altai: A collection of ethnographic articles and studies]. Moscow, Skoropech. A. A. Levenson. 221 p. (In Russ.)

Vosemnadtsat' stepnykh zakonov. Pamiatnik mongol'skogo prava XVI-XVII vv. [Eighteen laws of the steppes: A Monument of Mongolian law of the $16^{\text {th }}-17^{\text {th }}$ centuries] (2002) / transl. by A. D. Nasilov. St. Petersburg, Peterburgskoe vostokovedenie. 159 p. (In Russ.)

Gurvich, I. S. (1977) Kul'tura severnykh iakutov-olenevodov [The culture of Northern Yakut deer herders]. Moscow, Nauka. 245 p. (In Russ.)

Darzha, V. K. (2009) Traditsionnye muzhskie zaniatiia tuvintsev [Traditional Tuvan male pursuits]. Kyzyl, Tuvan publishing house. 592 p. (In Russ.)

D’iakonova, V. P. (1975) Pogrebal'nyi obriad tuvintsev kak istoriko-etnograficheskii istochnik [The funeral rite of the Tuvans as a historical and ethnographic source]. Leningrad, Nauka. 164 p. (In Russ.)

Zhamtsarano, Ts. (2001) Putevye dnevniki 1903-1907 gg. [The 1903-1907 travel diaries]. Ulan-Ude, BNTs SO RAN Publ. 380 p. (In Russ.)

Zelenin, D. K. (1936) Kul't ongonov v Sibiri. Perezhitki totemizma v ideologii sibirskikh narodov [The cult of Ongons in Siberia: Remnants of totemism in the ideology of the Siberian peoples]. Moscow, Leningrad, Nauka. 436 p. (In Russ.)

Kon, F. Ya. (1936) Za piat'desiat let [In fifty years]. 2nd ed. Vol. 3-4. Moscow, Sovetskii Pisatel' Publ. 344 p. (In Russ.).

Kulemzin, V. M. (1984) Chelovek i priroda $v$ verovaniiakh khantov [Man and nature in the beliefs of the Khanty]. Tomsk, Izd-vo Tomskogo universiteta. 187 s. (In Russ.)

Manzhigeev, I. A. (1978) Buriatskie shamanisticheskie $i$ doshamanisticheskie terminy. Opyt ateisticheskoi interpretatsii [Shamanistic and pre-Shamanistic terms in Buryat language: An attempt at atheistic interpretation]. Moscow, Nauka.125 p. (In Russ.)

Mikhailov, T. M.(1987) Buriatskii shamanizm: istoriia, struktura i sotsial'nye funktsii [Buryat Shamanism: History, structure and social functions]. Novosibirsk, Nauka. 282 p. (In Russ.)

Mitskevich, S. I. (1929) Menerik i emiriachen'e. Formy isterii v Kolymskom krae [Manerik and emiryachenie: Forms of hysteria in the Kolyma region]. Leningrad, Izd-vo Akademii nauk SSSR. 53 p. (In Russ.)

Miiagasheva, S. B. (2019) Semantika ritual'nogo lechebnogo tantsa andai u mongol'skikh narodov [The semantics of Andai ritual healing dance of the Mongolian peoples]. Vestnik Buriatskogo nauchnogo tsentra Sibirskogo otdeleniia Rossiiskoi akademii nauk, no. 3 (35), pp. 102-109. (In Russ.) DOI: 10.31554/2222-9175-2019-35-10-102-109

Mongush, M. V. (2012) Shamanizm i neoshamanizm v Tuve [Shamanism and Neo-Shamanism in Tuva]. In: Uchenye Zapiski Tuvinskogo Instituta Gumanirnykh Issledovanii. Vol. XXIII. Kyzyl, Tyvapoligraf. 612 p. Pp. 297-321. (In Russ.)

Nebesnaia deva-lebed'. Buriatskie skazki, predaniia i legendy [The Swan Maid of heaven: Buryat fairy tales, legends and legends] (1992) / comp. by I. E. Tugutov and A. I. Tugutov; transl. by A. I. Tugutov; comm. by I. E. Tugutov, A. I. Tugutov and L. N. Nurkaeva. Irkutsk, Vostochno-Sibirskoe knizhnoe izdanie [East Siberian book publication]. 368 p. (In Russ.)

Osokin G. M. (1906) Na granitse Mongolii. Ocherki i materialy k etnografii iugo-zapadnogo Zabaikal'ia [On the Mongolian border: Essays and materials for the ethnography of the south-western Transbaikalia]. St. Petersburg, Tipografiia A. S. Suvorina. 214 p. (In Russ.)

Pekarskii, E. K. (1959) Slovar' iakutskogo iazyka [A dictionary of the Yakut language]: in 3 vols. $2^{\text {nd }}$ ed. Moscow, AN SSSR. Vol. II. Issue 5-9. Columns 1281-2508. 641 p. (In Russ.)

Pintilei, N. V. and Cherkasova, E. S. (2013) Etiologiia i traditsionnye metody lecheniia psikhicheskikh zabolevanii v russkoi narodnoi meditsine [Etiology and traditional cures of mental illnesses in Russian traditional medicine]. Meditsina i obrazovanie $v$ Sibiri, no. 4 [online] Available at: http://ngmu.ru/cozo/mos/article/abauthors.php?id=1040 (access date 05.06.2021). (In Russ.)

Popov, A. A. (1949) Materialy po istorii religii iakutov byvshego Viliuiskogo okruga [Materials on the history of the religion of the Yakuts of the former Vilyui district]. In: Sbornik muzeia arkheologii $i$ etnografii [A collection published by the Museum of Archeology and Ethnography], vol. XI. 394 p. Pp. 257-323. (In Russ.)

Popov, A. A. (2008) Kamlaniia shamanov byvshego Viliuiskogo okruga [Ritual of communicating with spirits in shamans of the former Vilyui district]: texts. $2^{\text {nd }}$ ed. / comp. by R. I. Bravina. Novosibirsk, Nauka. 464 p. (In Russ.)

Radlov, V. V. (1989) Iz Sibiri : stranitsy dnevnika [From Siberia: Pages from a diary] / ed. by C. I. Vainshtein; transl. from Germ. by K. D. Tsivina and B. E. Chistova. Moscow, Nauka. 749 p. (In Russ.).

Rassadin, V. I. (1980) Mongolo-buriatskie zaimstvovaniia v sibirskikh tiurkskikh iazykakh [Mongolian-Buryat loanwords in Siberian Turkic languages]. Moscow, Nauka. 116 p. (In Russ.) 
Riabkov, P. (1887) Poliarnye strany Sibiri (zametki i nabliudeniia v Kolymskom okruge) [Polar countries of Siberia: notes and observations in the Kolyma district]. In: Sibirskii sbornik [The Siberian collection] / ed. by N. M. Iadrintseva. Vol. 1887. St. Petersburg, Tipografiia I. N. Skorokhodova. 278 p. Pp. 1-42. (In Russ.)

Semenova, N. B. (2019) Predposylki suitsidal'nogo povedeniia u detei i podrostkov korennykh narodov Sibiri: kognitivnye faktory riska. Chast' II [Prerequisites for suicidal behavior in children and adolescents of the indigenous peoples of Siberia: cognitive risk factors]. Suitsidologiia, vol. 10, no. 3 (36), pp. 19-31. (In Russ.)

Semke, V. Ya., Bogomaz, S. A. and Bokhan, T. G. (2012) Kachestvo zhizni molodezhi narodov Sibiri kak sistemnyi pokazatel' urovnia stressoustoichivosti [The quality of life in the youth of the peoples of Siberia as a system indicator of the level of stress resistance]. Sibirskii vestnik psikhiatrii i narkologii, no. 2 (71), pp. 94-98. (In Russ.)

Seroshevskii, V. L. (1993) Yakuty. Opyt etnograficheskogo issledovaniia [Yakuts. An attempt at ethnographic research]. Moscow, Moskovskaia tipografiia № 2.736 p. (In Russ.)

Sidorov, P. I., Medvedeva, V. V., Davydov, A. N. (2014) Isteriodemonicheskie istoki psikhicheskikh epidemii [Hystericaldemonic origins of mental epidemics]. Psikhicheskoe zdorov'e, no. 4, pp. 39-48. (In Russ.)

Sleptsov, P. A. (1972) Yakutsko-russkii slovar' [A Yakut-Russian dictionary]. Moscow, “Sovetskaia entsiklopediia” Publ. 568 p. (In Russ.)

Sodnompilova, M. M. (2019) Mezhdu meditsinoi i magiei: praktiki narodnoi meditsiny v kul'ture mongol'skikh narodov (XVII-XIX vv.) [Between medicine and magic: traditional medicine practices in the culture of the Mongolian peoples in $17^{\text {th }}-19^{\text {th }}$ centuries]. Moscow, Vostochnaia literatura. 205 p. (In Russ.)

Sodnompilova, M. M., Nanzatov, B. Z. (2020) «Kostnaia» versiia antropomorfnoi modeli v traditsionnom mirovozzrenii tiurko-mongolov Vnutrennei Azii: obrazy, znachenie, funktsii [The «bone» version of the anthropomorphic model in the traditional worldview of the Turko-Mongols of Inner Asia: images, meaning, functions]. Vestnik Arkheologii, Antropologii $i$ Etnografii, no. 4 (51), pp. 207-217. (In Russ.) DOI: 10.20874/2071-0437-2020-51-4-18

Solomatina, S. N. (1992) Materialy po shamanstvu u tuvintsev [Materials on shamanism among Tuvans]. In: Materialy polevykh etnograficheskikh issledovanii 1988-1989 gg. [Materials of field ethnographic research, 1988-1989] / ed. by Yu. Yu. Karpov. St. Petersburg, Nauka. Vol. 1. 180 p. Pp. 119-129. (In Russ.)

Tal'ko-Gryntsevich, Iu. D. (1903) K voprosu ob izuchenii fiziologicheskikh iavlenii polovoi zhizni zhenshchin v Zabaikal'e [On studying the physiological phenomena of women's sexual life in Transbaikalia]. In: Trudy TroitskosavskoKiakhtinskogo otdeleniia Priamurskogo otdela Imp. Russkogo geograficheskogo obshchestva [Proceedings of the TroitskosavskoKyakhtinsky branch of the Amur Department of the Imperial Russian Geographical Society]. St. Petersburg, Tipo-litografiia Gerol'dt. Vol. VI. Issue 1. 172 p. Pp. 95-135. (In Russ.)

Tatarintsev, B. I. (2000) Etimologicheskii slovar' tuvinskogo iazyka [An etymological dictionary of the Tuvan language]. Novosibirsk, Nauka. Vol. II. 387 p. (In Russ.)

Tatarintsev, B. I. (2008) Etimologicheskii slovar' tuvinskogo iazyka [An Etymological dictionary of the Tuvan language]. Novosibirsk, Nauka. Vol. IV. 442 p. (In Russ.).

Termen, A. I. (1912) Sredi buriat Irkutskoi gubernii i Zabaikal'skogo kraia. Ocherki i vpechatleniia [Among the Buryats of the Irkutsk Governorate and the Trans-Baikal Territory: Essays and impressions]. St. Petersburg, Tipografiia Ministerstva Vnutrennikh Del. 144 p. (In Russ.)

Traditsionnoe mirovozzrenie tiurkov Iuzhnoi Sibiri. Chelovek. Obshchestvo [The traditional worldview of Turkic peoples of South Siberia: Person and society] (1989) / L'vova E. L., Oktiabr'skaia I. V., Sagalaev A. M., Usmanova M. S. Novosibirsk, Nauka, Sibirskoe otdelenie. 243 p. (In Russ.).

Traditsionnaia kul'tura tuvintsev glazami inostrantsev (konets XIX - nachalo XX veka) [Traditional culture of Tuvans through the eyes of foreigners: late 19th - early 20th century)] (2002) / text prep., preface and commentary by A. K. Kuzhuget. Kyzyl, Tuvan book publisher. 224 p. (In Russ.)

Tiurkskie narody Vostochnoi Sibiri [The Turkic peoples of Eastern Siberia] (2008) / ed. by D. A. Funk and N. A. Alekseev. Moscow, Nauka. 422 p. (In Russ.).

Khangalov, M. N. (1959) Sobranie sochinenii [Collected works]: in 3 vols. Ulan-Ude, Buryat Book Publishing House. Vol. II. 442 p. (In Russ.)

Kherel, A. Kh. (2015) Prelomlenie zhanra narodnoi legendy v tuvinskoi dramaturgii (na materiale p’esy «Khaiyraan boot») V. Kok-oola [Transformation of the genre of folk legend in Tuvan drama: the play "Khayyraan Boot" by V. Kok-oola]. Vestnik Buriatskogo gosudarstvennogo universiteta, vol. 10(1), pp. 249-255. (In Russ.)

Tsybikov, B. D. (1970) Obychnoe pravo selenginskikh buriat [Common law about the Selenga Buryats]. Ulan-Ude, Buryat Book Publishing House. 282 p. (In Russ.)

Tsydenova, D. Ts. (2009) Predstavleniia aginskikh buriat o zhizni i smerti [The ideas of the Aginsky Buryats about life and death]. Novosibirsk, Redaktsionno-izdatel'skii tsentr NGU. 193 p. (In Russ.)

Yakuty. Sakha [Yakuts. Sakha] (2012) / ed. by N. A. Alekseev et al. Moscow, Nauka. 599 p. (In Russ.)

Räsanen, M. (1969) Versuch eines etymologisches Wörterbuch der Türksprachen. Helsinki. 533 p.

Submission date: 06.06.2021. 